\title{
4. Men, Modernity and Melanesia
}

\author{
Bruce M. Knauft
}

During the period of Donald Tuzin's impressive fieldwork-from the late 1960s through the mid-1980s - themes of traditional male cults and masculine assertion in Melanesia (MMMl) had special purchase in the anthropology of Oceania and more widely. By the 2000s, another triplicate - of mobile men with money (MMM2) - has gained particular purchase (for example, Lepani 2008), along with various other dimensions of modern masculinity. In many of these more recent treatments (see Taylor 2008), Melanesian masculinity is often seen through the lenses of guns, drunkenness and pronounced, often brutal, male violence.

In 1997, an articulation between the first of these emphases and the nascent academic awareness of the second was attempted in a powerfully provocative book by Donald Tuzin: The Cassowary's Revenge. The present chapter takes stock of these trends on the basis of significant changes in masculinity that I have been able to document among the Gebusi of Papua New Guinea's Western Province (Knauft 1985, 2002a, 2010).

Donald Tuzin's imposing documentation of Ilahita Arapesh male cults and masculine practices (for example, Tuzin 1976, 1980, 1997) harboured several themes. Parallel with the then-prominent focus on male warrior-hood and sexual antagonism in Melanesia (for example, Allen 1967; Herdt 1982; Herdt and Poole 1982; Langness 1967, 1974; Meggitt 1964), Tuzin posited a functional dimension to elaborate male secret-cult activity among Ilahita Arapesh: male cults cultivated, organised and brought coherence to male organisation-and violence - in ways that were both instrumentally productive and ultimately constitutive of its culture, including its beliefs, values and ethics. Tuzin's first book (1976) documented how the elaborate dual organisation of Ilahita Arapesh society integrated diverse and, to some extent, refugee groups into itself in a Durkheimian manner - enabling a demographically large and militarily powerful extended community to repel the raids and incursions of neighbouring Abelam and other groups. In his second major book, Tuzin (1980) demonstrated the deep underpinning of the Ilahita social, organisational and masculine ethic of controlled violence - and misogyny - in the elaborate practices, rituals and myths of the multi-stage Tambaran male secret cult. In his third and most controversial volume (1997), he proceeded, based on ethnographic re-study, to document the demise of the Tambaran cult, the accompanying destruction of Ilahita Arapesh traditional culture and the death, as he termed it, of Ilahita masculinity itself (for example, 1997:181). Finally, Tuzin drew ominous links 
between the alienation of Ilahita culture and the alienation of masculinity in the absence of all-male institutions that could offer 'sanctuary' (1997:Ch. 8). As such, he created a broad if not sweeping connection between masculine insecurities in Melanesia and what was then just coming to be seen as the need for a coherent 'men's movement', organised by and for men, in California and other parts of the United States. As Losche (this volume) suggests, Tuzin's last major book on the Ilahita Arapesh differs significantly from the rest of his work in having a different tonality - more personally engaged, emotionally open and provocative - that expands upon his overall corpus.

In the earlier literature of the 1960s through to the early 1980s, speaking broadly, anthropologists suggested that Melanesian male insecurity was fuelled by warfare and other threats to male corporate integrity - and that the male response was collective bonding through ritual and social cult organisations exclusive to men and, commonly, institutionalised sexual antagonism that collectivised men over and against women. Though the functionalist assumptions of this line of reasoning were highly open to critique from feminist perspectives, more recent social changes have created a set of conditions that transformed and also maintained these tensions (however they arose to begin with). In particular, Melanesian masculinity has been threatened by increasing social emphasis on, but also great practical impediments to, obtaining money and Western commodities. Without these, men's status has been compromised, especially in relation to outsiders and the previous colonial presence (see discussion in Knauft 1997).

Consistent with the fact that commodity goods and money are often or typically considered individual in possession in Melanesia-notwithstanding their additional possible use in, or conversion for, collective exchange transactionscontemporary threats to masculinity in Melanesia have dovetailed with the de-collectivisation and individuation of masculine social life as widely reported in the literature on Melanesian social change, including male youth violence, criminal activity, opportunistic and/or extramarital sexuality and urban violence, including by so-called raskols (for example, Hart Nibbrig 1992; Strathern 1993; Wardlow 2007; cf. Haley 2008). Rather than fuelling traditionally collective and institutionalised sexual antagonism between men and women within communities, the modern inflection of gendered tension has arguably resulted in more focused individual and domestic, rather than collective, gendered antagonism (for example, Wardlow 2009). With the demise of collective cult activities, central longhouses or their equivalent, and the mythic and ritual moral authority of elders, younger men (as reported by Tuzin and many others) have been less restrained in individual aggressive or violent 
assertiveness towards women as well as with other men, including within the community, than they had often been before (for example, Sykes 1999). As a result:

Male status remains culturally and morally dependent - in some ways more so than previously - on constraining female sexuality and limiting women's wider cultural and economic relationships. Male insecurity, opposition to women, and the desire for male collectivity have been reinstated in new guises at the same time that they have disengaged from customary institutions such as the male cult, the men's house, or the warrior society. At the same time, male social life involves an increasing proportion of transient and non-traditional affiliations, including workgroups and the relation of male comradeship through leisure activities such as drinking or gambling, which require money. (Knauft 1997:250)

These patterns are not disjoined or disarticulated from previous trends so much as they draw upon them in new contexts and guises amid individualised pressures. As Lipset (this volume) puts it, one now has at a minimum two alternative, local 'Symbolics' in Melanesian societies such as the Murik-the one made up of pre-state institutions and the other consisting of modernitywhich together give rise to unpredictable, complicated chains of signification.

As pointed out by Holly Wardlow (Personal communication), an important link in reinforcing contemporary patterns of masculine insecurity and male violence is the threat posed not just by women in general but by the individualisation of women's agency under contemporary conditions - including the active or potentially active participation of women as agents in church, markets, in town and city businesses - and as sexual agents, including as 'wanton women' or pasinja meri (Wardlow 2006). Resentment and constraint against women by Melanesian men, often accompanied by a palpable sense of violent backlash against them, are prominent themes in an important suite of papers edited as a special issue of The Australian Journal of Anthropology by John Taylor (2008). In this and other works, the link between gendered change, masculinity and locally and regionally modern challenges to men seems substantively born out and amplified.

In significant respects, Donald Tuzin's later work (1997) illustrates this pattern from within a local village context; he considers a detailed case of male alienation and frustration in the wake of the demise of a key, if not all-encompassing, male cult system. Beyond Tuzin's premonition of deep anomie, however, he had little evidence or inkling of the extent and intensity of Melanesian male aggressiveness that were brewing in the modern Melanesian context, including in the nexus between alcohol, drugs and guns - nor of the great variations bequeathed from past traditions that were developing across Melanesia. 
MacIntyre suggests for Melanesia that '[b]eer drinking and, to a lesser extent, marijuana use have become the quintessential ways that masculine sociality is expressed and they provide the means for expressing relations of conflict, aggression, and retribution' (2008:190). Furthermore,

its most negative social effect is the way beer consumption and use of guns have become behaviours that differentiate men with wealth and power from those who have none... The image of a 'man with a gun,' primed for action, is pervasive in PNG and connotes not only the state's capacity to use force, but that of men to fight their own battles and to resist and subvert state control. (MacIntyre 2008:190)

Even among the Gebusi, who presently have a minimal rate of male violence, almost half of the schoolboys when asked to draw a picture of what they wanted to be when they grew up drew elaborate pictures of themselves as police officers or soldiers in the PNG Defence Force (Knauft 2002a:199-200).

Viewed in historical and cultural context, however, it remains important to consider current trends without positing them as a violent consequence of Melanesian modernities alone. For instance, as Bell (2006), Lipset (2006) and Halvaksz (Halvaksz 2006; Halvaksz and Lipset 2006) have illustrated, while the introduction and use of marijuana in Papua New Guinea connect with the perception of modern social ills, they also illustrate longstanding continuities of trade and exchange, substantialisation of personhood, and generational conflicts between senior and younger men.

In many areas of Melanesia, rates of violence and killing during the pre-colonial era, including in societies with active men's cult societies, were likely at least as high if not much higher than those presently evident (Knauft 1990). Though there is some truth to the suggestion that, prior to colonialism, ritualised male authority helped to channel and orchestrate male aggression from an intra to an inter-group focus, much of this functionalist reasoning is undercut by the fact that many forms of violence were more frequent and intense prior to colonial pacification. That ethnography grounded in structural-functionalist assumptions had its heyday during a period of relative late-colonial calm, during which social institutions from the past could be documented without experiencing the intensity of their prior violent actualisation, easily magnifies this sense of a 'palaeo-terrific', in which Melanesian masculinity was functionally ordered on its own except as disrupted by external forces and influences. At any rate, as MacIntyre notes:

Studies of the violence of men in marginalized indigenous communities have in various ways attributed contemporary emphases on aggressive, self-assertive individualism to the emasculating effects of colonialism... 
attributing contemporary violence to the breakdown of 'traditional' inter-generational authority structures...This historicist, exculpatory approach to the issue works at an abstract level but fails utterly as an explanation for any specific acts of violence. (MacIntyre 2008:187)

To concretise these issues in the present case - and to provide a complementary perspective - we can consider recent changes in masculinity and in violence among the Gebusi of Papua New Guinea. By 1998, Gebusi had experienced major changes that paralleled in some respects those documented by Tuzin (1997) for the Ilahita Arapesh. Longhouses had disappeared, initiations were no longer practised, indigenous costuming had been largely relegated to folkloric displays for government ceremonies, Christianity had supplanted traditional spirit rituals and seances, and communication with the unseen spirit-world forces was negligible. Among Gebusi as well as the Ilahita Arapesh, as Lipset puts it in his contribution to this volume, 'cultic men lost their position as the object of desire in society'. The rate of Gebusi violence - which included a very high homicide rate that made up 32.7 per cent of all adult deaths, mostly the execution of accused sorcery suspects - dropped to a fraction of this and then to zero after 1989 (Knauft 1985).

Along with these changes, and helping to account for them, was the post-colonial advent of Christianity, schooling for children, government development projects, a cash-based semi-weekly market, the mushrooming of small local stores, sports leagues and reliance on police to settle severe disputes and deal with the threat of significant physical violence (Knauft 2002a, 2002b). In terms of masculinity per se, I did not sense the anomie or alienation among Gebusi men that Tuzin reported for the Ilahita Arapesh but rather a decentralisation of male social life and an increasing modern 'bravado' of masculine speech styles, hortatory and urban-style dress and music, all of which contrasted with previous ritualised ways of asserting and maintaining masculine status, including through rituals of male initiation and traditional dancing (for example, Knauft 2010:Ch. 10).

Upon returning to the Gebusi 10 years later, in 2008, I was concerned to know whether the previous pattern of locally modern but non-lethal masculinity I had found a decade earlier would be continued - or overthrown as patterns of modern frustration, resentment and lack of economic development continued in this out-of-the-way corner of Papua New Guinea. My concern was magnified during my re-entry to the area, as the local airstrip had been closed due to poor maintenance, government inefficiency and neglect, and virtually all government workers at the local Nomad Sub-District Office had consequently left for Kiunga or other towns or cities in Papua New Guinea. As a result, local government services - including the elementary school, police force, development projects, sports leagues and folklore celebrations and sponsorships-were all defunct. The subdistrict health centre had no doctors or medicines, and the Nomad 
market had become desultory, affording few goods, fewer buyers and highly inflated prices for any outside commodities. Given that the region has no roads to other parts of the country and was highly dependent on the local airstrip, the closure of its airfield and the departure of the wage-paid government employees caused a collapse of the cash economy of the Nomad Subdistrict, including for the Gebusi communities within it.

How did Gebusi respond to these difficult circumstances? Against my expectations, the Gebusi living in the communities of my past association and study - the constituent hamlets of Gasumi Corners - had developed a striking resurgence of customs and practices that had been moribund and, I thought, virtually dead 10 years before, in 1998 (see Knauft 2010:Ch. 12). By 2007, a new central longhouse had been built. Male initiations were once again held, and traditional dancing, with costumes identical to those in 1980, was highly in evidence (cf. Lipset, this volume, concerning the persistence of male-cult activity among the Murik). Collective male etiquette that included the sharing of home-grown tobacco smoked from long bamboo pipes, the collective drinking of locally prepared kava, and heightened male sexual banter, camaraderie and horseplay were all pronounced. In significant ways, Gebusi male ethos was more similar in 2008 to what it had been in 1980 than to what I had observed and experienced during the Gebusi's locally modern phase in 1998.

Subsistence patterns had also become more traditional. In 1998, the dominant local crop was sweet potatoes - both for local consumption and to sell to cashwielding family members of government officials at the Nomad market. Raising sweet potatoes required the Gebusi in Gasumi Corners to keep their pigs caged and fodder fed on the other side of the broad Kum River - that is, away from their root-crop gardens. Ten years later, in 2008, the domesticated pigs were back in the village. Root-crop gardens had been depleted and not replenished, and there was little incentive to cultivate produce for the Nomad market. In contrast, subsistence activity had returned more concertedly to the large expanse of the primary rainforest. In short, Gebusi resuscitated infrastructural as well as cultural patterns that were reminiscent of their pre-colonial past.

Some customs had not resurfaced or been rejuvenated. These included male spirit mediumship and men's collective seance communication with indigenous spirits for advice and divination. So, too, the rate of active sorcery divination, accusation and violent attack or execution of sorcery suspects had never resurfaced to its previous extraordinarily levels; it remained low to nonexistent. No homicides had occurred in my communities of association or were known from other neighbouring Gebusi communities during the preceding 10 years. As such, the homicide rate among the 150-odd persons whose descendants I had known well since 1980 had continued to be zero between 1989 and 2008, despite an extraordinarily high homicide rate among their predecessors from 
approximately 1940 to 1975 . Though my stay was not long enough to effectively gauge changes in domestic violence or marital relations, the impressions I did have were that these were largely unchanged and were not more antagonistic than they had been either in 1998 or in 1980-82.

In some selective ways, to revisit earlier ethnographic contributions, Gebusi changes reaffirm possibilities that I think Don Tuzin would have liked, even if he did not envisage or imagine them for the Ilahita Arapesh or more generally. On the one hand, a palpable male collective social life based on camaraderie and longstanding collective ritual expression has again become alive and well among Gebusi. On the other hand, some of the more troubling traditional concomitants of this ritual, spiritual and cultural system - including extremely high rates of violent sorcery attribution and homicide - have been effectively reduced to very low levels, and this pattern has continued for more than two decades, from the late 1980 s to at least 2008.

How and why Gebusi developed and are maintaining their present pattern of rejuvenated male social life but without significant violence - and after a period of intense locally modern adoptions during the 1990s (see Knauft 2002a) are both important and challenging questions. It cannot be easily claimed that Gebusi patterns are widely evident across Melanesia. Gebusi themselves suggested in 2008 that neighbouring Bedamini peoples to the east had significant problems with marijuana use, the quest for guns, a sense of cultural alienation and elevated rates of male aggression.

In contrast with many peoples in Melanesia, Gebusi retain their distinct ability to return to the land and subsistence regimes that supported local populations for decades if not longer in the pre-colonial past. They have not been subject to significant wage labour, out-migration, cash cropping or the opportunities and challenges of connection by roads to other parts of the country. As such, they appear to have a particular potential as well as motivation under present conditions to rediscover or reinvent previous ways of being while also retaining introduced orientations, including Christianity, increasingly on their own terms.

After being first contacted by Australian patrols in 1962-63, Gebusi were effectively bypassed amid the colonial effort to pacify the more populous and militaristic Bedamini people to their east. On the other hand - also in contrast with many other groups in Melanesia-Gebusi had been on the verge of becoming a remnant population incorporated by aggressive neighbours. Perhaps consistent with this, they have not had a strong sense of their own cultural history or elevated cosmological past, even among the senior generation, against which current developments are seen as morally abased or degenerated. This historical 
and cultural context informs the Gebusi's 'presentist' emphasis, including their strikingly robust orientation to new, locally modern ways of life during the 1990s when these were most actively within their reach (Knauft 2002a).

As several contributions to this collection emphasise, including those by Lipset and Losche, large-scale arguments all too easily generalise or stereotype Melanesian gender relations and features of masculinity in particular. From nineteenth-century images of bloodthirsty Melanesian savages and midtwentieth-century views of functionally controlled male ritual systems to early twenty-first-century views of male Hobbesianism - an almost Lord of the Flies perception of Melanesian male aggression-accounts have projected Western fears, or Western hopes, onto Melanesians (Knauft 1990; cf. Dinnen and Ley 2000). Against the grains of truth or significance that have informed and undergirded such generalisations in each case, individual Melanesian societies and circumstances evince their own distinctive development. On the one hand, for instance, the challenging and often troubling current trends of Melanesian masculinity as documented in Taylor (2008) appear to have significant purchase in various parts of Melanesia. As an overall emphasis, however, this orientation risks 'basket-casing' Melanesia and threatens to put the region back in the savage slot to which it has been relegated for much of anthropology's professional past (cf. Trouillot 1991).

Against this, it is important to reassert the importance in cultural anthropology of taking local cultural and historical features at their face value. Notwithstanding globalisation, and indeed because of locally derived appropriations of modernity (Knauft 2002b), Melanesia's diversity continues to belie generalities that derive primarily from a single group or a small cluster of societies, be it the Gebusi, the Ilahita Arapesh, the Enga, the Huli, the Lahiri people, the Murik, or others. Amid current economic retrenchment, the cutting back or collapse of rural government services and proliferating local ways of responding to new conditions across Papua New Guinea, Solomon Islands, Vanuatu and Fiji-not to mention West Papua and New Caledonia - it is hard to imagine that the cultural diversity of Melanesia, and of Melanesian masculinities, will wither rather than widen.

This suggests that a further emphasis in current perspectives is in order-an MMM3: a renewed awareness of our own continuing tendency, to misjudge Melanesian men. To historicise this misjudgment, we might recall the death of traditional Melanesian cultures that has been so sombrely predicted, inaccurately, since the mid-nineteenth century, including the widespread development of so-called 'salvage anthropology'. It is important not to downplay either the persistence of longstanding patterns of Melanesian belief or the orientation or periods and even epochs of great cultural reorientation, change and transformation. Both of these patterns continue as beliefs and practices 
from one period settle and morph upon those bequeathed from another. Some older patterns might never resurface while others lie dormant to be resuscitated in new guises of resurgence or rediscovery. In the mix, older patterns change if not transform even as they persist, while newer patterns establish continuities even as they break from the past.

Rosier and darker views of Melanesian masculinities might be considered in this light. For several centuries at least, much of Melanesia has seen patterns of violent male behaviour along with elaborate - and wonderful — cultural systems of belief and orientation that both reinforce and transcend or outstrip them. The remarkable diversity of these patterns is likely to continue. Amid this trend, it is easy to overlook exceptions to dominant current perceptions, including specific cultural environments, segments of social life, and masculinities that seem relatively peaceful or at least non-violent and pro-social. The Gebusi in current circumstances appear to fit this last characterisation.

In conclusion, I should register a limitation that the perspectives of Don Tuzin and I- our differences notwithstanding - have both in significant ways failed to transcend. This is the lack of an adequately articulated view of femalecentred perceptions, actions and beliefs to parallel that of men's. Barlow and Lipset's (1997) discussion of the complementary and also dialogic aspects of Murik male and female perspectives is particularly important and illustrative in this regard. The truism that gender relations are neither male nor female is still rather inadequately confronted in much contemporary anthropology, including both an emphasis on men to the relative exclusion of women and the tacit complementary assumption that gendered anthropology is largely in fact an anthropology of women or of femininity. As the work of Holly Wardlow and others attests (see Hirsch et al. 2009), the task of documenting and articulating Melanesian male and female orientations often yields great ethnographic and analytic benefit even though - and in some ways for the very reason that - it can be difficult for a single primary researcher to initiate and methodologically maintain such complementary gendered perspectives during fieldwork.

In their introduction to this volume, Lipset and Roscoe describe Donald Tuzin as an 'anthropologist's anthropologist'. In my own experience, this is especially true of Don's ethnography. Tuzin's three big books on the Arapesh - The Ilahita Arapesh, The Voice of the Tambaran and The Cassowary's Revenge-are all marvels of intricate and nuanced ethnographic portraiture. By itself, detailed ethnography is not unusual; for a great number of world areas, one can find scores of rigorous scholarly monographs, however dry and tedious they might otherwise be. What sets Tuzin's work apart is his writerly ability not just to make the wonderful nuance of ethnography come alive but to construct a larger portrait, configure a broader purpose and, in the process, tell a bigger story. This makes Tuzin's ethnographic contributions endearing - and also provocative (see 
Losche, this volume). Agree or disagree with his theoretical premise or analysis, the depth, richness and sheer power of his portrayals, mounting as they do towards crescendos of larger signification, force you to examine exactly how, when and for what reasons you might diverge from his view. Don Tuzin was both an ethnographer of cultural artistry and an ethnographic artist. Would that we could all be so lucky - or enjoy the process as much as Don himself always seemed to do.

\section{References}

Allen, Michael 1967. Male Cults and Secret Initiations in Melanesia. Melbourne: Melbourne University Press.

Barlow, Kathleen and David Lipset 1997. Dialogics of Material Culture: Male and Female in Murik Outrigger Canoes. American Ethnologist 224(1):4-36.

Bell, Joshua 2006. Marijuana, Guns, Crocodiles, and Submarines: Economies of Desire in the Purari Delta. Oceania 76:220-34.

Dinnen, Sinclair and A. Ley (eds) 2000. Reflections on Violence in Melanesia. Canberra: Asia Pacific Press.

Gregor, Thomas and Donald F. Tuzin (eds) 2001. Gender in Amazonia and Melanesia. Berkeley: University of California Press.

Haley, Nicole 2008. Sung Adornment: Changing Masculinities at Lake Kopiago, Papua New Guinea. The Australian Journal of Anthropology 19:213-29.

Halvaksz, Jamon 2006. Drug Bodies: Relations with Substance in the Wau Bulolo Valley. Oceania 76:235-44.

Halvaksz, Jamon and David Lipset 2006. Another Kind of Gold: An Introduction to Marijuana in Papua New Guinea. Oceania 76:209-19.

Hart Nibbrig, N. E. 1992. Rascals in Paradise: Urban Gangs in Papua New Guinea. Pacific Studies 15:115-34.

Herdt, Gilbert H. 1981. Guardians of the Flutes: Idioms of Masculinity. New York: McGraw-Hill.

Herdt, Gilbert H. (ed.) 1982. Rituals of Manhood: Male Initiation in Papua New Guinea. Berkeley: University of California Press.

Herdt, Gilbert H. and Fitz John P. Poole 1982. 'Sexual Antagonism': The History of a Concept in New Guinea Anthropology. Social Analysis 12:3-28. 
Hirsch, Jennifer S., Holly Wardlow, Daniel Jordan Smith, Harriett H. Phinney, Shanti Parikh and Constance A. Nathanson (eds) 2009. The Secret: Love, Marriage, HIV. Nashville, Tenn.: Vanderbilt University Press.

Knauft, Bruce M. 1985. Good Company and Violence: Sorcery and Social Action in a Lowland New Guinea Society. Berkeley: University of California Press.

Knauft, Bruce M. 1990. Melanesian Warfare: A Theoretical History. Oceania 60:250-311.

Knauft, Bruce M. 1997. Gender Identity, Political Economy, and Modernity in Melanesia and Amazonia. Journal of the Royal Anthropological Institute 3:233-59.

Knauft, Bruce M. 2002a. Exchanging the Past: A Rainforest World of Before and After. Chicago: University of Chicago Press.

Knauft, Bruce M. 2002b. Trials of the Oxymodern: Public Practice at Nomad Station. In Bruce M. Knauft (ed.) Critically Modern: Alternatives, Alterities, Anthropologists, pp. 105-43. Bloomington: Indiana University Press.

Knauft, Bruce M. 2010. The Gebusi: Lives Transformed in a Rainforest World. Second edition. New York: McGraw-Hill.

Langness L. L. 1967. Sexual Antagonism in the New Guinea Highlands. Oceania 37:161-77.

Langness L. L. 1974. Ritual Power and Male Domination in the New Guinea Highlands. Ethos 2:189-212.

Lepani, Katherine 2008. Mobility, Violence, and the Gendering of HIV in Papua New Guinea. The Australian Journal of Anthropology 19:150-64.

Lipset, David 2006. Tobacco, Good and Bad: Prosaics of Marijuana in a Sepik Society. Oceania 76:245-57.

MacIntyre, Martha 2008. Police and Thieves, Gunmen and Drunks: Problems with Men and Problems with Society in Melanesia. The Australian Journal of Anthropology 19:179-93.

Meggitt, Mervyn J. 1964. Male-Female Relationships in the Highlands of Australian New Guinea. American Anthropologist [Special Publication] 66(4):204-24.

Read, Kenneth E. 1959. Leadership and Consensus in a New Guinea Society. American Anthropologist 61:425-36. 
Strathern, Andrew 1993. Violence and Political Change in Papua New Guinea. Pacific Studies 16:41-60.

Sykes, Karen 1999. After the 'Raskol' Feast: Youth's Alienation in New Ireland, Papua New Guinea. Critique of Anthropology 19:157-74.

Taylor, John P. 2008. Changing Pacific Masculinities: The 'Problem' of Men. The Australian Journal of Anthropology 19:125-35.

Trouillot, Michel-Rolph 1991. Anthropology and the Savage Slot: The Poetics and Politics of Otherness. In Richard G. Fox (ed.) Recapturing Anthropology: Working in the Present, pp. 17-44. Santa Fe, NM: School of American Research Press.

Tuzin, Donald F. 1976. The Ilahita Arapesh: Dimensions of Unity. Berkeley: University of California Press.

Tuzin, Donald F. 1980. The Voice of the Tambaran: Truth and Illusion in Ilahita Arapesh Religion. Berkeley: University of California Press.

Tuzin, Donald F. 1997. The Cassowary's Revenge: The Life and Death of Masculinity in a New Guinea Society. Chicago: University of Chicago Press.

Wardlow, Holly 2006. Wayward Women: Sexuality and Agency in a New Guinea Society. Berkeley: University of California Press.

Wardlow, Holly 2007. Men's Extramarital Sexuality in Rural Papua New Guinea. American Journal of Public Health 97:1006-14.

Wardlow, Holly 2009. 'Whip Him in the Head With a Stick': Marriage, Male Infidelity, and Female Confrontation Among the Huli. In Jennifer S. Hirsch, Holly Wardlow, Daniel Jordan Smith, Harriett H. Phinney, Shanti Parikh and Constance A. Nathanson (eds) The Secret: Love, Marriage, HIV, pp. 136-57. Nashville, Tenn.: Vanderbilt University Press. 